\title{
The environmental knowledge and pro-environmental behavior of future engineers in Morocco
}

\author{
Zakaria Ait taleb ${ }^{1}$, Mounia El Farouki ${ }^{1}$, and Mehdi El Mejdoub ${ }^{1}$ \\ ${ }^{1}$ Hassan II University, Casablanca, Morocco
}

\begin{abstract}
During the recent decades, raising the level of environmental awareness has become one of the main social goals, which has reached a level of social and political consensus never seen before. Education can be the catalyst that changes people's behavior regarding the environment (Zsóka et al., 2013; Schultz, 2014). Many studies have demonstrated a positive link between education level and pro-environmental behavior (Fernandez-Manzanal et al., 2007; Levine and Strube, 2012; Meyer, 2015; Monier et al., 2009). In Morocco, as in many countries of the world, human behavior towards the environment has been defective. However, the country has been taking a number of steps to protect the environment. There have been few researchers investigating the role of universities as agents contributing to environmental awareness, especially engineering schools. Engineering work has a significant effect on the world. The advent of engineers, engineering work, and engineering schooling is closely related to countries development (Downey and Lucena 2004, Downey and Lucena 2005). This paper aims to analyze the relationship between 3 factors: the sources of environmental issues, the acquired knowledge and the pro-environmental behavior to protect the environment. In order to do that, a survey of 141 engineering students has been assessed in 5 different engineering schools and the results have then shown that the sources of information is the internet and this source doesn't lead to accountability of the individuals. Furthermore, the taken actions for the environment rarely include trash sorting, paper and meat consumption.
\end{abstract}

\section{Introduction}

Nowadays, concern for the environment is at the center of debates. This is due to the climatic and environmental threats that weigh on our world.

Sharing the same concern with the rest of the world, Morocco aims to achieve better management of its environment through various protection measures, in particular through administrative and educational supervision (COSEF, 1999).

Thus, school is considered one of the places where education needs to take this environmental approach into consideration. Environmental education is an ongoing process. It is important to focus on it because it helps to create responsible companies that respect the environment. (Clugston, 2004) state that the community plays a fundamental role and represents one of the major agents of environmental education and sustainable development. Also, higher education aims to develop responsible and competent individuals who are endowed with skills and values that contribute to a world of continual change.

(Lozano, 2006; Wright, 2007; Waas et al., 2010; Zilahy and Huisingh, 2009) argue that today's students have a major impact on the future of the environment, which makes institutionalization issues of sustainability in education very relevant. This approach contributes to responsibility and citizenship.
The purpose of the current study is to explore the level of environmental awareness in Morocco. Also, this research aims to analyze the relationship between three factors: The environmental awareness, the sources of information about the environment and the proenvironmental behavior that results from them.

\section{Theoretical framework}

\subsection{Definition of environmental awareness}

Environmental awareness refers to "the attitude towards the environmental consequences of human behavior". Beginning with the typical definition of attitude, environmental awareness can be defined as a predisposition to react to environmental issues in a certain manner (Culiberg and Rojšek, 2008).

Even though, the perception of environmental awareness is instinctively clear to most people. There is no clear definition of this concept.

In some cases, the difference between attitude and behavior is not clearly distinguished, and the abovementioned terms are equated with terms such as environmental responsibility and environmental behavior.

It should be noted that a person who cares about the environment is not automatically considered a green consumer. Being a consumer requires behaving in a 
certain way. Environmental awareness is an essential step before becoming a green consumer (Carlson, 2004: 46).

\subsection{Measures of environmental awareness}

Measuring environmental awareness based on scientific criteria has become important in various fields.Two studies were considered.

As a first type of research, two main categories of factors must be distinguished:

- Internal factors: bringing together elements such as consciousness, motivation, values, attitudes, and also knowledge.

- External factors: such as economic, institutional, social or cultural factors.

The second type of research evaluated the influence of one or more specific variables on a very particular proenvironmental behavior and in a certain context, through qualitative and quasi-experimental methods. (Bonaiuto, Carrus, Martorella \& Bonnes, 2002; Chhokar, Dua, Taylor, Boyes \& Stanisstreet, 2011; Cialdini, Reno \& Kallgren, 1990; Corraliza \& Berenguer, 2000; Hadjichambis, Paraskeva -Hadjichambi, Ioannou, Georgiou \& Manoli, 2015; Heimlich \& Ardoin, 2008; Humphreys \& Blenkinsop, 2018; Kerry et al., 2013; Skamp et al.,2009).

\subsection{Studies that have measured the awareness}

Research regarding environmental awareness and correlation factors that impact it sometimes offer inconsistent results. However, contradictory study outcomes and also a large variety of regulating variables spread the idea that scholars disagree on the concept of environmental awareness (Carlson, 2004: 81).

The implicit aspects of environmental awareness can be understood with the help of a three-pronged attitude model. Environmental awareness is a multifaceted notion comprising a cognitive, affective and conative component (Dembkowski and Hanmer-Lloyd, 1994: 594).

Moreover, one study of 30 countries explained differences in student performance across countries studied by modernity and school system characteristics (in each country) rather than socio-economic status. Similarly, (Werning, Löser and Urban, 2008) found a link between student performance and the presence of specific support for poor-performing students.

\subsection{The universities and their role in training socially responsible deciders}

Disterheft et al., 2012 claim that higher education contributes to national development through the production, collection and dissemination of specialized knowledge and skills.

Universities play a vital role in the evolution and transformation of societies by providing education to future decision-makers and leaders with new qualifications and skills to develop a more sustainable society and reduce the environmental impact of their daily practices and activities.

The abilities may have become the cradle for the training of future leaders. Universities establishments should respond to the different needs of local societies. Especially, in this current context of climate change where it is becoming urgent to counter this phenomenon. Universities should aim to incorporate sustainability into their teaching and research programs promoting environmental issues.

The engineers and managers of the future should incorporate the knowledge acquired in terms of environmental protection into their mindset in order to minimize material consumption and waste emissions.

\subsection{The Moroccan government efforts toward environmental preservation}

The environmental challenge has nowadays become a central topic. This can be explained by all the environmental, climatic and energy threats that our planet goes through. Morocco is not an exception. The country has the same concern and he aims to install a better management of its environment. These aspirations require the existence of varied environmental protection measures, among which we mention the administrative and educational framing (COSEF, 1999); (MEN, 1999).

In Morocco as in several countries in the world, man's behavior towards the environment has been awfully flawed (Asslouj, Kholtei, Amrani-Paaza, \& Hilali, 2007; Boukhoubza et al., 2008).

In its strategic vision of the 2015-2030, the Higher Council for Education, Training and Scientific Research (CSEFRS, 2015) focused a special attention on the prevalence of "incivility behaviors at the level of the school and their environment such as non-respect for the environment and the public good". However, several studies have examined the factors influencing responsible environmental behavior (Chawla and Cushing, 2007; Cialdini, Reno and Kallgren, 1990; Corraliza and Berenguer, 2000; Hines, Hungerford and Tomera, 1987; Hungerford and Volk, 1990; Kollmuss And Agyeman, 2002; Malandrakis, Boyes and Stanisstreet, 2011; Pruneau et al., 2006; Skamp, Boyes and Stannistreet, 2009).

\subsection{The role of engineers in developing awareness}

Engineering work has a significant effect on the world. The advent of engineers, engineering work, and engineering schooling is closely related to country development (Downey and Lucena 2004, Downey and Lucena 2005).

(Campbell, 2002) recognizes that engineers have been part of the problem but are also potentially part of the solution and that now the role of engineers may be more about safeguarding the quality of the remaining resources. Sustainable development policies need to focus on matters of equity and fair allocation of resources and 
opportunities, but these are seldom taken into account by engineers (Herkert, 1998).

The engineer should be seeking to build an infrastructure which is ecologically viable, energy and resource efficient, and provides healthy, vibrant and cohesive living spaces.

Since 1994, Environmental Training in Engineering Education (ENTRE) conferences have been organized that mostly dealt with environmental efficiency issues in education of engineers.

A number of engineering schools have embraced that sustainable development should be a required course for all students. Some made such a course compulsory, Others made it an elective.

\subsection{Universities and schools actions to increase environmental awareness}

There has been rare research investigated the role of universities as agents contributing to environmental education either explicitly or implicitly. (Synodinos, 1990; Shetzer et al., 1991; Benton, 1994; Dunaway, 1999).

In fact, few of the researchers have approached the role of universities as means for increasing people's environmental knowledge (Orr, 1995; Wilke, 1995).

According to this perspective, global environmental education should be carried out at least partly in schools and universities, as it fits perfectly with their existing mission of creating responsible citizens.

Scholars have paid little attention to the role of universities as explicit and implicit environmental educators. Past research focused on the variance of knowledge levels of students with different specializations (e.g. Synodinos, 1990; Shetzer et al., 1991; Benton, 1994; Dunaway, 1999) and few scholars studied how universities could help increase people's knowledge about the environment (Orr, 1995; Wilke, 1995).

Education can be the catalyst that changes an people's pro-environmental behavior (Zsóka et al., 2013; Schultz, 2014). Many studies have demonstrated a positive link between education level and pro-environmental behavior (Fernandez-Manzanal et al., 2007; Levine and Strube, 2012; Meyer, 2015; Monier et al., 2009). Also, Some evidence suggests that energy saving behavior increases with higher levels of education (Mundaca et al., 2010).

Universities' research activities stimulate innovation and deliver solutions to social and environmental issues (Duderstad and Weber, 2011).

\section{Methodology}

The objective of the research was to uncover the relationship between the environmental awareness and the actions taken by engineering students to protect the environment. The ultimate goal of the research was to formulate recommendations for universities and engineering schools in Morocco to reinforce their ability to increase awareness among future engineers.
For that purpose, we studied the current knowledge of the students, its sources, the level of taken responsibility regarding the environment then at last we analyzed the impact of the source of knowledge on the quality of that knowledge and the impact of the later on the protective actions taken for the government.

The main assumptions of the research were the following:

a) Levels of environmental knowledge would strongly correlate to the degree of students' environmental education (Asunta, 2004; Michalos et al., 2009; Marjainé et al., 2010).

b) Environmental knowledge, pro-environmental attitudes, consumer behavior and the everyday lifestyles of students are strongly interrelated factors which are not consistently correlated (Bamberg, 2003; Kagawa, 2007; Boyes et al., 2008 and Michalos et al., 2009).

c) University students would be more aware of environmental issues than high school students, due to the extent and focus of environmental education, as well as their ages (Asunta, 2004).

In order to test these assumptions, a survey was prepared for engineering schools (age 18 à 24) in Morocco.

The sample counts 141 students from 5 Engineering schools, 2 in private and 3 public institutions. Those students have various ethnic and national origins along with various sources of information regarding the environmental challenges. The questions were meant to evaluate the knowledge of the students regarding the studied topic, along with the questions regarding actions taken to protect the environment.

To assess the level of knowledge of environmental issues the question asked were:

What are the main sources of pollution? What is the main source of energy in Morocco? What pollutes rivers and oceans? What causes the extinction of species?

The questionnaire has been answered in October 2020 in EMSI, HESTIM, INPT, EHTP and ENSEM.

\section{Results}

The collected Data has been analyzed through $\mathrm{khi}^{2}$ tests, and linear regression with SPSS IBM. To study the correlation between three main factors: the source of information, the knowledge the students have about the environmental challenge and finally the actual actions taken to protect the environment.

Before proceeding to the hypothesis testing, a fiability test needs to be made:

\begin{tabular}{|r|r|}
\hline \multicolumn{2}{|c|}{ Statistiques de fiabilité } \\
\hline $\begin{array}{l}\text { Alpha de } \\
\text { Cronbach }\end{array}$ & $\begin{array}{c}\text { Nombre } \\
\text { d'éléments }\end{array}$ \\
\hline 774 & 9 \\
\hline
\end{tabular}

The cronbach alpha has a value above 0,77 which means the measure scales are reliable. 
Besides, a few variable crossings have been made to explore more in depth the obtained results.

\section{H1: The source of information and the knowledge.}

\begin{tabular}{|c|c|c|c|}
\hline \multicolumn{4}{|c|}{ Tests du Khi-deux } \\
\hline & Valeur & ddl & $\begin{array}{l}\text { Signification } \\
\text { asymptotique } \\
\text { (bilatérale) }\end{array}$ \\
\hline Khi-deux de Pearson & $20,102^{a}$ & 5 & , 001 \\
\hline $\begin{array}{l}\text { Rapport de } \\
\text { vraisemblance }\end{array}$ & 24,498 & 5 &, 000 \\
\hline $\begin{array}{l}\text { Nombre d'observations } \\
\text { valides }\end{array}$ & 141 & & \\
\hline
\end{tabular}

The $\mathrm{Khi}^{2}$ test does indeed reveal a dependence between the sources of information and the acquired knowledge. In fact, the sources of information regarding the environmental challenges are the internet then television followed by the university. Specifically, are impacted by the source of information about :

- The source of pollution is impacted by the source of information.

- The garbage disposal in Morocco is impacted by the source of information.

- The water pollution is impacted by the source of information.

- The role of the Ozone is impacted by the source of information.

Also the perceived most responsible actor in preserving the environment is strongly related to the source of information. Those who believe the state is the most responsible have learned their information from the net. But those who believe they are responsible for the environment have acquired their knowledge from 3 main sources: The school, the net and the television.

\section{$\mathrm{H} 2$ : Source of information and protective actions}

\begin{tabular}{|l|r|r|r|}
\hline & \multicolumn{1}{|c|}{ Valeur } & \multicolumn{1}{c|}{ ddl } & \multicolumn{1}{c|}{$\begin{array}{c}\text { Signification } \\
\text { asymptotique } \\
\text { (bilatérale) }\end{array}$} \\
\hline $\begin{array}{l}\text { Khi-deux de Pearson } \\
\begin{array}{l}\text { Rapport de } \\
\text { vraisemblance }\end{array}\end{array}$ & $45,675^{\text {a }}$ & 4 &, 000 \\
$\begin{array}{l}\text { Nombre d'observations } \\
\text { valides }\end{array}$ & 53,889 & 4 &, 000 \\
\hline
\end{tabular}

The source of information impacts all the protective actions taken to preserve the environment except for the meat consumption and the garbage sorting.

\section{H3: The Knowledge and actions}

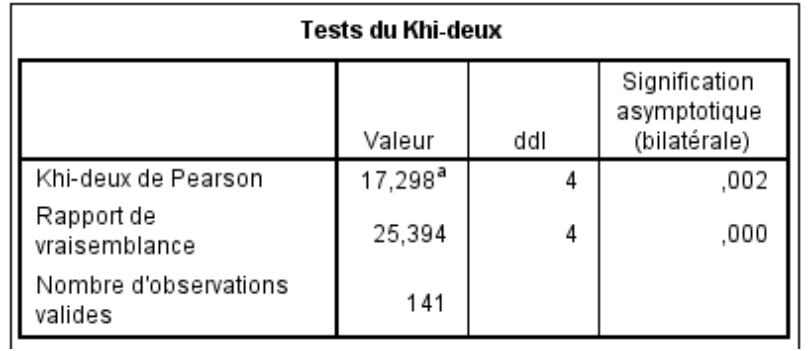

As with the source of information, the knowledge impacts all the Pro-environmental behavior to preserve the environment except for the meat consumption and the garbage sorting with the addition of the use of paper that is not correlated with the knowledge.

\section{Discussion}

One of the main challenges of this study is that researchers often have a different understanding of pro-environmental behavior than their respondents. Conflicting research results, as well as an unusually large number of influencing variables, have led to the hypothesis that researchers do not always share the same concept of environmental awareness (Carlson, 2004). To that issue, this research based its results on a test of correlation of variables.

As an outcome to this study, the respondents have shown that the source of information impacts not only the level of knowledge regarding the environment but also the actions taken. Also, another finding is that the university plays a role undeniable in helping the students acknowledge the environmental issues in a more persuasive way that helps them engage in proenvironmental actions.

Meanwhile, students believe that pro-environmental actions can enhance their image among peer groups and make them feel good. Making personal sacrifices to benefit the environment can enhance one's positive selfimage (Venhoeven et al.,2013).

As for how the engineering schools can empower the awareness, other researchers have proven that conferences, seminars and development programs inform and help increase awareness on sustainability. Workshops and faculty development programs do enhance the role model behavior by educating the educators (Lukman et al., 2013). On that basis it is highly recommendable for engineering schools to put more focus on increasing awareness among their students especially with the usage of multimedia and online education in environmental education will be very useful (Rohwedder, 1999; Rohwedder \& Alm, 1995). Therefore, It is very important to assess the knowledge of individuals on the environment, ecology, or pollution and their attitudes towards these issues during or after periods of education (Maloney, Wand, \& Braucht, 1975) to reinforce their understanding and attitudes towards the issue. Mobile technologies should be used to increase environmental awareness of students. 


\section{Conclusion}

This research aimed at detecting the sources of environmental knowledge and the behavior that results on it. As a result of this study, we have found that the actions taken to protect the environment are impacted by the level of awareness as well as the source of information. While (A. Sayed et all 2014) have shown that in high schools of fes the level of awareness is overall still weak, our research has confirmed that the information taken from the internet doesn't make the individual feel responsible about the subject. and this figure is the most common. Those results confirm that the role of the engineering schools is to be reinforced in order to not only inform but also responsibility the students as the internet's role remains mainly informative without clear orientations.

In fact, few studies have examined the association between environmental concern and environmentally responsible behavior. According to the results from attitude research, such an association can only be expected under certain conditions. For example, (Stern \& Oskamp 1987) drew the conclusion that environmental concern correlates with environmentally responsible behavior only if the attitude and behavior are measured at the same level of specificity, and if the behavior is easy to perform. Other research has shown that environmentally responsible behavior is influenced by various factors, of which environmental concern is only one. Additional factors influencing behavior are knowledge (Stern, 1992), locus of control (Hines et al., 1987),

This research provides evidence regarding the important role that the engineering school plays as a source of information about the environmental issues. Moreover, the engineering school can play an important role as well in generating the proper eco-friendly attitude. Those results can be used by further researches to explore more in depth that role of engineering schools, ways to raise the awareness efficiently and to suggest a model for accompanying students towards a fully useful knowledge and attitude to address the topic. Also, those results help practitioners know what can be currently expected from freshly graduated engineers, and how the country can form environment conscious engineers in the future.

More research can show what specific means can lead to a better assimilation of the concept and the role of the engineer.

\section{References}

1. Á. Zsóka, Z.M. Szerényi, A. Széchy, T. Kocsis Greening due to environmental education? Environmental knowledge, attitudes, consumer behavior and everyday pro-environmental activities of hungarian high school and university students", (Journal of Cleaner Production 48 126-133) (2013)

2. P.W .Schultz, S. Oskamp, T. Mainieri Who recycles and when? A review of personal and situational factors (Journal of Environmental Psychology 15 105-12) (1995)

3. R.Fernández-Manzanal, L. Rodríguez-Barreiro, J. Carrasquer Evaluation of environmental attitudes:
Analysis and results of a scale applied to university students (Science Education 91 988-1009) (2007)

4. D.S. Levine, M.J. Strube Environmental attitudes, knowledge, intentions and behaviors among college students (The Journal of social psychology 152308 326) (2012)

5. A. Meyer Does education increase proenvironmental behavior? Evidence from Europe Ecological Economics 116 108-121) (2015)

6. S. Monier, D. Hassan, V. Nichèle, M. Simioni Organic food consumption patterns (Journal of agricultural \& food industrial organization 7 12-23) (2009)

7. G.L. Downey, J.C. Lucena Knowledge and professional identity in engineering history and technology 20 393-420) (2004)

8. G.L. Downey, J.C. Lucena National identities in multinational worlds : engineers and engineering cultures (International journal of Continuing Engineering Education and Lifelong Learning) (2005)

9. R. Clugston The UN Decade of Education for Sustainable Development (Soka Gakkai International Quarterly, Buddhist Perspectives on Peace Culture and Education, 38 1) (2004)

10. R. Lozano Incorporation and institutionalization of SD into universities: Breaking through barriers to change (Journal of Cleaner Production 14 787-796) (2006)

11. T. S. A. Wright Giving "teeth" to an environmental policy: A delphi study at Dalhousie university (Journal of Cleaner Production 14 761-768) (2006)

12. T. Waas, A.Verbruggen, T. Wright University research for sustainable development: Definition and characteristics explored (Journal of Cleaner Production 18 629-636) (2010)

13. G. Zilahy, D. Huisingh The roles of academia in regional sustainability initiatives (Journal of Cleaner Production 17 1057-1066) (2009)

14. B. Culiberg, I. Rojšek, Understanding environmental consciousness: a multidimensional perspective (2008)

15. M.Bonnes, M. Bonaiuto Environmental psychology: from spatial-physical environment to sustainable development (Handbook of environmental psychology 28-54) (2002)

16. K. Chhokar, S. Dua, N. Taylor, E. Boyes M. Stanisstreet indian secondary students views about global warming : beliefs about the usefulness of actions and willingness to act (International journal of Science and Mathematics Education , 91167 1188) (2011)

17. R. B. Cialdini, R.R Reno, C. A. Kallgren, A focus theory of normative conduct: Recycling the concept of norms to reduce littering in public places. (Journal of personality and social psychology, 58(6), 10151026) (1990)

18. J. A Corraliza, J. Berenguer Environmental values, beliefs, and actions: A situational approach Environment and behavior, 32(6), 832-848 (2000)

19. A. C. D Hadjichambis, Paraskeva-Hadjichambi, H.Ioannou, Y.Georgiou, C. C. Manoli, Integrating 
sustainable consumption into environmental education: a case study on environmental representations, decision making and intention to act. (International Journal of Environmental and Science Education, 10(1), 67-86) (2015)

20. J. E Heimlich, N. M Ardoin Understanding behavior to understand behavior change: A literature review. (Environmental education research, 14(3), 215-237) (2008)

21. C. Humphreys, S. Blenkinsop Ecological identity, empathy, and experiential learning: A young child's explorations of a nearby river. (Australian Journal of Environmental Education, 34(2), 143-158) (2018)

22. J. Kerry, D. Pruneau, M. Cousineau, M. A. Mallet, B. Laliberté, J. Langis Faire naître l'espoir et l'autoefficacité chez les jeunes par l'action environnementale communautaire (Revue canadienne d'éducation, 36(4), 3-32) (2013)

23. D. H. Carlson, Environmental Concern in South Africa : The Development of a Measurement Scale, masters paper, University of South Africa (2004)

24. S. Dembkowski, S. Hanmer-Lloyd The Environmental Value-Attitude-System Model: A Framework to Guide the Understanding of Environmentally-Conscious Consumer Behavior (Journal of Marketing Management, 10, 593-603 (1994)

25. R. Werning, J. M. Löser, M. Urban Cultural and social diversity: An analysis of minority groups in istepiserman schools (The Journal of Special Education) 42-47 (2008)

26. A. Disterheft et al. Environmental management systems (EMS) implementation processes and practices in European higher education institutions: top-down versus participatory approaches (Journal of Cleaner Production 31, 80e90) (2012)

27. L. Chawla, D. F. Cushing Education for strategic environmental behavior (Environmental Education Research) 13(4), 437-452) (2007)

28. J. A Corraliza, J. Berenguer, Environmental values, beliefs, and actions: A situational approach (Environment and behavior 32(6), 832-848) (2000)

29. D. Pruneau, A. Doyon, J. Langis, L.Vasseur, E. Ouellet, E. McLaughlin, G. Martin When teachers adopt environmental behaviors in the aim of protecting the climate. (The Journal of Environmental Education, 37(3), 3-12) (2006)

30. J. M Hines, H. R.Hungerford, A. N. Tomera Analysis and synthesis of research on responsible environmental behavior: A meta-analysis (The Journal of environmental education, 18(2), 1-8) (1987)

31. H. R. Hungerford, T. L. Volk Changing learner behavior through environmental education. (The journal of environmental education, 21(3), 8-21) (1990)

32. A. Kollmuss, J. Agyeman Mind the gap: why do people act environmentally and what are the barriers to pro- environmental behavior? (Environmental education research, 8(3), 239-260) (2002)

33. K. Skamp, E.Boyes, M. Stannistreet Global warming responses at the primary secondary interface 1. students' beliefs and willingness to act (Australian Journal of Environmental Education, 25, 15-30) (2009)

34. G. Malandrakis, E. Boyes, M. Stanisstreet Global warming: Greek students' belief in the usefulness of pro-environmental actions and their intention to take action. (International journal of environmental studies, 68(6), 947-963) (2011)

35. A. Campbell The world summit on sustainable development: a view from an engineer. (Ingenia 14 59-61) (2002)

36. JR. Herkert Sustainable development, engineering and multiple corporations: ethical public policy implications (Science and Engineering Ethics 4: 333346) (1998)

37. N. Synodinos Environmental attitudes and knowledge: A comparison of marketing and business students with other groups (Journal a/Business Research 20 161- 170) (1990)

38. L. Shetzer, R. W. Stackman, F.L. Moore BusinessEnvironment Attitudes and the new environmental paradigm (The journal of Environmental Education 22) (1991)

39. R. Benton Does an environmental course in the business school make a difference? (The Journal of Environmental Education 24 37-43) (1993)

40. D. Orr Educating for the environment: higher education's challenge of the next century, (Change, 27 43-46) (1995)

41. R. Wilke Environmental literacy and the college curriculum: colleges and universities have a challenge to meet (EPA Journal 21 28-30) (1995)

42. Á. Zsóka, Z.M Szerényi, A. Széchy, T. Kocsis Greening due to environmental education? Environmental knowledge, attitudes, consumer behavior and everyday pro-environmental activities of of Hungarian high school and university students (Journal of Cleaner Production) (2013)

43. R. Fernández-Manzanal, L. Rodríguez-Barreiro, J. Carrasquer Evaluation of environmental attitudes: Analysis and results of a scale applied to university students( Science Education, Vol. 91 No. pp.9881009) (2007)

44. L. Mundaca, L. Neij, E.Worrell, M. McNeil Evaluating energy efficiency policies with energyeconomy models (Annual Review of Environment and Resources 35 305-344) (2010)

45. J.J. Duderstadt, L. Weber Global sustainability and the responsibilities of universities (Economica, London) 2012

46. T. Asunta Knowledge sources, attitudes and selfreported behavior of secondary-level science students concerning environmental topics. (Current Research on Mathematics and Science Education) (2004)

47. A.C. Michalos, H. Creech, C. McDonald, P.M. .Hatch Kahlke Measuring Knowledge, Attitudes and Behaviors towards Sustainable Development: two Exploratory Studies (International Institute for Sustainable Development, Winnipeg) (2009) 
48. Marjainé, Szerényi Zs, Á. Zsóka, A.Széchy, Behavior of the students attending Corvinus University of Budapest, with regard to sustainability 145-164) (2010)

49. S. Bamberg How does environmental concern influence specific environmentally related behaviors? A new answer to an old question (Journal of Environmental Psychology 23 21e32) (2003)

50. F. Kagawa Dissonance in students' perceptions of sustainable development and sustainability (International Journal of Sustainability in Higher Education 8) (2007)

51. E. Boyes, K. Skamp, M. Stanisstreet Australian secondary students' views about global warming: beliefs about actions, and willingness to act (Research in Science Education 39) (2008)

52. L. A. Venhoeven, J. W. Bolderdijk, L. Steg Explaining the paradox: how pro-environmental behavior can both thwart and foster well-being Sustainability 5 1372-1386) (2013)

53. R. Lukman, R. Lozano, T.Vamberger, M. Krajnc Addressing the attitudinal gap towards improving the environment: a case study from a primary school in Slovenia (Journal of Cleaner Production 48 .93100) (2013)

54. W.J. Rohwedder Environmental education goes high-tech. (Nature Human 1-2) (1999)

55. W.J. \& Alm, A.Rohwedder, Using computer in environmental education: Interactive multimedia and on-line learning. http://www.nceet.snre.umich.edu /Compiters/pp (1995)

56. M.P. Maloney, M.P. Ward, G.N. Braucht Psychology in action - A revised scale for the measurement of ecological attitudes and knowledge (American Psychologist, July, 787-790) (1975)

57. P. C. Stern, S. Oskamp Managing scarce environmental resources (Handbook of Environmental Psychology ZZ 1043-1088) (1987)

58. J. M. Hines, H. R. Hungerford, A. N. Tomera Analysis and synthesis of research on responsible environmental behavior: a meta-analysis (The Journal of Environmental Education, 18) (1986-87) 